UDC 78.035.2:78.071.2(436.1)

DOI: 10.24919/2519-058x.16.210909

\title{
Bohdan YAKYMOVYCH
}

PhD hab. (History), Honored Worker of Culture of Ukraine, Professor of the Department of Historical Local History, Historical Faculty, Ivan Franko National University of Lviv, 1 Universytetska Street, Lviv, Ukraine, postal code 79000 (b.yakymovych@gmail.com)

ORCID: http://orcid.org/0000-0003-1597-1128

ResearcherID: AAS-6157-2020

\section{Oksana VELYCHKO}

PhD (Art Sciences), Associate Professor of Department of Musical Art, Faculty of Culture and Arts, Ivan Franko National University of Lviv, 1 Universytetska Street, Lviv, Ukraine, postal code 79000 (oksavel16@gmail.com)

ORCID: http://orcid.org/0000-0002-3346-0893

ResearcherID: AAS-6368-2020

\section{Богдан ЯКИМОВИЧ}

доктор історичних наук, заслужений працівник культури Украӥни, професор кафедри історичного краєзнавства історичного факультету Львівського національного університету імені Івана Франка, вулиия Університетська, 1, Львів, Україна, індекс 79000 (b.yakymovych@gmail.com).

\section{Оксана ВЕЛИЧКО}

кандидатка мистецтвознавства, доцентка кафедри музичного мистецтва факультету культури і мистецтв Львівського національного університету імені Івана Франка, вул. Університетська, 1, Львів, Украӥна, індекс 79000 (oksavel16@gmail.com)

Бібліографічний опис статті: Yakymovych, B. \& Velychko, O. (2020). Creative work of the early Viennese classics in historical retrospective. Skhidnoievropeiskyi Istorychnyi Visnyk[East European Historical Bulletin], 16, 28-35. doi: 10.24919/2519-058x.16.210909

\section{CREATIVE WORK OF THE EARLY VIENNESE CLASSICS IN HISTORICAL RETROSPECTIVE}

\begin{abstract}
The purpose of the research is to analyze the achievements of early Viennese classics through the historical prism of Empress Maria-Theresa's reign, who was the promoter and financed the musical culture in her country. The methodology of the research is based on the use of historical, source, musicological, culturological approaches, which allowed to analyze the activities of the Habsburg era musicians, who created the basis for the emergence of Viennese musical Classicism. The scientific novelty consists in the formulation of the mentioned research vector and the research material systematization of that historical epoch, which concerns the analysis of the works of early Viennese royal court composers and performers, who are little known to the general public. The Conclusions. Thus, there were significant reform changes in the cultural, socio-state and religious life of the Austrian Empire during the reign of Empress Maria-Theresa (1740 - 1780). The musical life of Vienna was characterized by the intensity and developed forms of music and concert practice.
\end{abstract}


Old Viennese musicians of Maria-Theresa era created a favourable foundation for the activities of Viennese musical classics, laying the foundations in all areas of the artistic process - composer's creative work, performing practice, pedagogue's practice, music education infrastructure and concert entertainment institutions. Among the galaxy of contemporary composers-performers stood out the figures of G. K. Wagenzail, G. Reuter, M. G. Monn, J. Starzer and J. K. Manna, who were united by a common geographical location (the city of Vienna) and the same period of time (the reign of Maria-Theresa), which coincided with the peak of their creative activity. According to E. Braudo, each of the representatives of Old Viennese school individually "strengthened the foundations of the new instrumental style, both in symphonic and instrumental music" (E. Braudo).

Key words: Maria-Theresa, the Habsburgs, Vienna, early Viennese classics, composer, creative activity.

\title{
ТВОРЧИЙ ДОРОБОК СТАРОВІДЕНСБКИХ КЛАСИКІВ В ІСТОРИЧНІЙ РЕТРОСПЕКТИВІ
}

\begin{abstract}
Анотація. Мета роботи - проаналізувати доробок старовіденських класиків крізь культурно-історичну призму доби правління імператрииі Марї-Терезії (1740 - 1780 рр.), спираючись на опрачьовані джерелознавчі матеріали. Методологія дослідження трунтується на застосуванні історичного, джерелознавчого, музикознавчого, культурологічного підходів, які дали змогу висвітлити діяльність музикантів Габсбурзької доби, що створили підтрунтя для появи віденського музичного Класииизму. Наукова новизна полягає у постановиі вектора означеної розвідки та систематизації дослідницького матеріалу тісї історичної епохи, щио стосується аналізу творчості старовіденських придворних композиторів та виконавиів, маловідомих широкому загалові. Висновки. У часи правління імператрииі Марії-Терезії (1740 - 1780 рр.) у культурному, суспільнодержавному й релігійному житті Австрійської імперії відбулися значні реформаторські зміни. Музичне життя Відня характеризувалося інтенсивністю та розвиненими формами музично-кониертної практики. Старовіденські музиканти доби Марії-Терезї̈ створили сприятливе підтрунтя для діяльності віденських музичних класиків, заклавщи основи у всіх ияаринах мистецького процесу - композиторській творчості, виконавській практииі, педагогічній галузі, інфраструктурі музичної освіти та кониертно-видовищних установ. 3-поміж плеяди тогочасних композиторів-виконавиів виділялися постаті Г. К. Ватензайля, І. Ройтера, М. Г. Монна, Й. Штариера та Й. К. Манна, яких об'єднує спільне місие географічного розтамування(місто Відень) й однаковий часовий відтинок (правління Марії-Терезії), на які припав пік їхньої творчої активності. За словами Є. Браудо, кожен з представників старовіденської школи індивідуально "укріплював основи нового інструментального стилю, як в симфонічній, так і в інструментальній музииі" (Е. Браудо).

Ключові слова: Марія-Терезія, Габсбурги, Відень, старовіденські класики, композитор, творча діяльність.
\end{abstract}

The Problem Statement. A retrospective interest in the creative work of unknown to the general public composers and performers of the early classical period (or Old Viennese classics), the contemporaries of the Archduchess of Austria, Queen of Hungary and Bohemia Maria-Theresa, prompted the authors of the article to meticulous work in the archives (Österreichisches Staatsarchiv, Wien; Allgemeines Verwaltungsarchiv (AVA), Wienbibliothekin Rathaus - in German) and other music libraries in Vienna. In particular, the goal was to study the contribution of the Habsburg musicians, who created the basis for Viennese classics - J. Haydn, W. A. Mozart and L. van Beethoven. The names of their predecessors (G. K. Wagenzail, G. Reuter, M. G. Monn, J. Starzer, J. J. Fuchs, J. K. Mann, etc.) are little known, and their creative work is not sufficiently investigated. This fact determines the choice of the topic of this article and its topicality.

The Analysis of Recent Researches. Among some publications on this topic, in which the very topic is elucidated indirectly, it is worth noting the monographs of E. Braudo(Braudo, 1925), 
O. Shushkova (Shushkova, 2002) and L. Kirillina (Kirillina, 1996), devoted to aesthetics, stylistic features and a musical form of early classical music and musical practice of a classical style. Naturally, the early Viennese classics received more research attention by Austrian researchers, in particular, N. Scholz-Michelitsch (Scholz-Michelitsch, 1972; 1980), G. Hausswald (Hausswald, 1952), K. von Wurzbach-Tannenberg, K. Fastl, W. Garten, A. D. P. Taylor (Taylor, 2002) and the others.

The purpose of the research is to analyze the achievements of early Viennese classics through the historical prism of Empress Maria-Theresa's reign, who was the promoter and financed the musical culture in her country.

The Statement of the Basic Material. The synergy of a composer's activity and performance, typical of this era, created a holistic image of the musician of that period. The artists formed the principles of a pedagogical activity, which spread among the wealthy part of the society, as their creative practice depended on the commitment of "elite" people of the royal court. The royal court composers are meant, who created a new musical style, a new approach to the development of art and favoured the emergence of Classicism.

In 1740 Maria Theresa, a daughter of Karl VI, became the successor of the Holy Roman Emperor Karl VI (Maria Theresia Walburg Amalia Christina) (1717 - 1780), known in Austria as the "Queen Mother", who reigned for about 40 years. She initiated the reforms in the spirit of "an educated absolutism", took care of science and art flourishing, initiated the opening of universities, higher schools of drawing, painting and architecture. She reformed gymnasiums, created conditions for education (Schulordnung - in German), opened public libraries in Prague and Innsbruck, observatories in Vienna and Graz. Maria Theresa was assisted in this activity by Prince Duke Wenzel Anton Dominique Kaunitz-Rietberg (KaunitzRietberg) (1711 - 1794), who was engaged in the foreign policy of the Holy Roman Empire, spread the ideas of the Enlightenment, promoted humanitarian reforms, took care of science and art. He was a famous collector. Under his influence, education developed, textbooks were written, new subjects (History, Literature) were studied, and the others. Maria Theresa pursued a flexible religious policy, in particular, in 1774 she founded the Greek Catholic seminary Barbareum at the Church of St. Barbara. It was the time of active reforms in all areas, which were continued by her son Joseph II. According to the famous scientist, an authoritative specialist in the studies of the Austrian Empire, a historian Alan John Percival Taylor (1906 - 1990), "Maria-Theresa was a real founder of the Austrian Empire, stopping her reforms on the border with Hungary, she also became the founder of dualism" (Taylor, 1955, p. 18).

We should cite one very valuable opinion of the English historian to make this era more understandable. Describing the situation when the Habsburg power with the end of the reign of Karl V (he abdicated in 1556) led to the situation when in the second half of the XVIth century disintegration became very dangerous for the dynasty. The Habsburgs signed the alliance with the Jesuits, which led to the defeat of Protestantism in Central Europe. A. J. P. Taylor pointed out rightly (Taylor, 1955, pp. 13-14): “Austrian Baroque civilization, as if the buildings erected by it, was grandiose outside and empty inside; it was a theatre, not a reality. It lacked integrity and originality, its core was a desperate frivolity... Deep feelings were found only in music, the least politicized of the arts, and even there the spirit of creativity had to break its chains, and Viennese air corresponded more to the searches of J. Haydn (in fact, he developed the traditions of Viennese Classicism)". Finally, this is what the introductory part of the fundamental German-language multivolume edition is about "The 
Habsburg Monarchy 1848 - 1918" (“Die Habsburger Monarchie 1848 - 1918”). At the same time, there was the rise in the Austro-German literature, closely related to the Enlightenment (the works of E. E. Lessing, I. G. Herder, J. V. Goethe, J. F. Schiller, I. Kant, G. G. Hegeliat and the others).

It should be noted that at that time, music was directly connected with socio-political and social change. At the end of the Baroque era, a new social aesthetics matured, worldview changed, and science and art developed fruitfully. The changes began with the late Baroque Italian cultural hegemony in Vienna. New musical aesthetics continued in Old Viennese school. The first half of the XVIIIth century became a period of radical changes in the field of instrumental performance - and in the matter of instrumentation, and in the manner of playing various instruments, in the theoretical basis of learning, in social forms of concert and theatrical life. At that time keyed M. Pallotta was in demand instruments were used in concert practice, the attention was paid to solo performance (piano concerts). The formation period of solo and chamber music took place in close connection with the development of performance and domestic music: from trio-sonata - to symphony, sonata, concert, quartet, trio, duets. These tendencies are observed in the creative work of J. B. Sammartini, J. Tartini, G. M. Monna, G. K. Wagenzail and the others.

Vienna, as the centre of European music culture at that time, was largely linked to Italian, German (Mannheim and Berlin) schools, due to its favourable geographical location. The musical atmosphere of Vienna contributed to the artistic development. The royal court welcomed exquisite music, the patron of which was the Habsburg royal court. Creativity of the royal court composers: J. J. Fuchs, A. Caldar, M. Pallotta, G. T. Mufattabula was in demand among the elite and was respected.

The musical activity of Italian composers, who worked in Vienna and Austrian artists became the impact to form Old Viennese school, the founders of which are considered to be the Italian composer Antonio Caldara (1670 - 1736) and the Austrian composer Johann Joseph Fux (1660 - 1741). In their work there dominated vocal genres (operas, oratorios, etc.). From the 1740-ies there was an intensive development of a symphonic music, which became the dominant to Old Viennese composers. Their first symphonies appealed to instrumental forms taken was in demand from Italian music, such as the three-part structure of the overture to Neapolitan opera. The Austrian symphonic style was influenced by the tradition of home music (in German - Hausmusik), close to entertaining music, especially dance music. At that time, many professional and amateur instrumental ensembles appeared, performing suites (from fashionable dances at that time), serenades, nocturnes, cassations, divertissements, etc. Dance rhythms had a national colour.

Old Viennese school was represented by well-known contemporary composersperformers: Georg Reutter $(1708$ - 1772), who tended to the suite (intrada, largeto, minuet, finale), Georg Christoph Wagenseil (1715 - 1777), Matthias Georg Monn (1717 - 1750), Josef Starzer (1726 - 1787), Johann Christoph Mann (1726 - 1782). Although they lived and created in one and the same city - Vienna, their activities were quite diverse, and not concentrated around royal court, and creative tastes were excellent.

M. G. Monn, one of the main representatives of Old Viennese school, is considered to be the creator of a new type of symphony, which was later adapted by J. Haydn in his creative work. In 1740 M. G. Monn wrote the Symphony D-dur, in which Part I - sonata allegro, with a clear second theme and bright development, Part III - minuet, which was a novelty at that time (and it was 20 years before J. Haydn!). M. G. Monn's orchestra had the composition 
similar to a classical one ( 2 flutes, 2 oboes, 2 bassoons, horns and a group of fiddlesticks musical instruments). His creative output is 16 symphonies, a number of quartets, sonatas, chamber works for violin and piano, mass (in Latin - missa). In the field of piano sonata M. G. Monn is considered to be the predecessor of W. A. Mozart (Braudo, 1925, p. 91). At the same time, the artist was not influenced by other schools - Mannheim and Berlin. Another early Viennese composer, a concertmaster of Vienna royal court chapel Josef Starzer worked for a long time in St. Petersburg. In 1771 he founded a music society in Vienna, which became a center of active artistic activity. J. Starzer was the author of music for ballets, and his close cooperation with choreographers (J. J. Nover, G. Angelini, etc.) influenced the style of the performances "Apollo and Daphne" (1764), "Adele de Pontier" (1773), "Fascinating School" (1781). The artist's works include symphonies, the oratorio "The Passion of Jesus Christ" (1778), instrumental ensembles and concerts. The sacred music and operas were the most valuable in the creative heritage of the composer J. J. Fuchs. He conducted pedagogical activities successfully, in the list of his students are the following ones: G. C. Wagenzail, Gottlieb Muffat (1690 - 1770), Jan Dismas Zelenka (1679 - 1745), František Tůma (1704 1774), Ignaz Holzbauer (1711 - 1783).

Among Old Viennese classics stands out the figure of a brilliant pianist and organist Georg Christoph Wagenzail, a student of J. A. Weger, J. J. Fuchs and G. Muffat. His compositional works included a number of sacred works (17 masses, Requiem), 3 oratorios, 16 operas, 43 cantatas, 103 concerts, mainly for piano, 120 works for organ, 36 symphonies, 93 chamber instruments, arias (Scholz-Michelitsch, 1980). The piano work of G. C. Wagenzail deserves a special attention. Being closely connected with Mannheim school, G. C. Wagenzail subtly reincarnated the folk original, was the creator of a new formation music, combining the traditions of the Baroque with a gallant and sensual style, the Rococo forms, anticipating the achievements of the successors - J. Haydn and W. A. Mozart. The tragedy of G. C. Wagenzail consisted in the following fact - the artist remained in the shadow of Viennese classics: "He is the main representative of the early classical Viennese school, whose works paved the way for the classical style" (Scholz-Michelitsch, 1980, p. 5). G. C. Wagenzail also wrote a thorough theoretical work "Gradusad Parnassum" (1725), on the basis of which music theorists of the next era L. Busler $(1838$ - 1900), H. Bellermann $(1832$ - 1903) and K. K. Jeppesen (1892 - 1974) created a series of works on harmony, polyphony and counterpoint. The talent of a pianist and organist allowed G. C. Wagenzail to substitute his teacher J. J. Muffat as a piano teacher of Maria-Theresa and her husband Franz I of Lorraine.

On May 6, 1736, the first Mass of "Missaspei" (Mass of Hope) was successfully performed in Laxenburg Chapel, which illustrated the successful compositional start of G. C. Wagenzail. In 1737 there were held eight concerts at which his sacred music was presented, in particular, Magnificat for four solo voices, two solo violins and trumpets, a four-part choir and a large orchestra with woodwind instruments. In his liturgical works, G. C. Wagenzail was a follower of the traditions of J. J. Fuchs, whose favourite student he was. The works of G. C. Wagenzail demonstrate a talent for a melodic ingenuity, a successful balance between polyphonic exposition and melody, a musical language close to a folk song. In 1745 in Venice in the theater San Giovanni Crizostomo owing to the royal court the first opera by G. C. Wagenzail's "Ariodante" on the libretto by A. Salvi. Interestingly, a contemporary of the composer, a librettist P. Metastasio (1698 - 1782) expressed his point of view that the music of the opera "is not quite graceful" (Scholz-Michelitsch, 1980, p. 17). This can be explained by the fact that the Italians did not appreciate the Austrian musicians. 
Later, G. C. Wagenzail wrote the opera "Coronation of Titus", specially for Maria-Theresa, as gratitude for Venetian opera benefit. The opera was staged on Maria-Theresa's birthday.

In the XVIIIth century there was a traditional concept of a concert as a public paid spectacle, with a pre-announced programme in a specially adapted hall. Such hall became Burg Theater: "It was a center of music education, concerts took place three times a week, so there was an urgent need to write new works for the royal court and the townspeople" (Hausswald, 1952, p. 19). G. C. Wagenzail worked actively in this direction, writing works for public concerts. In general, contemporaries praised the work of the composer, noted the new original author's style, the presence of musical and plot culminations, emphasized a special melody, thematic richness. These characteristics made the composer closer to the opera reform of C. W. Gluck and became the basis for the masterpieces of W. A. Mozart. "He can be considered one of the most important opera composers at Viennese royal court in the mid-XVIIIth century. The music of G. C. Wagenzail's contains the unrest of the transition period... Subtle and original treatment of thematic ideas, the beauty of musical lines, a bright harmony and timbre, attention to poetic details in the dominance of music as a creative force, are the characteristics of the composer's works", - said N. Scholz-Michelitsch, a researcher (Scholz-Michelitsch, 1980, pp. 24-25).

The pedagogical activity of the artist deserves a special attention. In the list of his students are: J. Haydn (1732 - 1809), F. K. Dussek (1731 - 1799), L. Hoffmann (1738 - 1793), F. Tyber (1758 - 1810), even Maria-Theresa, her husband and children. For many pedagogues, the piano work of G. C. Wagenzail became the basis of the pedagogical repertoire, in particular, for the children of Leopold Mozart (1719 - 1787) - Nannerl and Wolfgang Amadeus. To fill the pedagogical repertoire G. C. Wagenzail created 14 works for piano, or harpsichord with general bass, piano concertos, musical works for two, three harpsichords, divertissements, suites and sonatas. The Music Archive at Musikferein in Vienna houses two of the composer's manuscripts "Fondamentopour L'accompagnement" and "Fondamentoperie Clavicembal" pedagogical textbooks, which illustrate his thorough approach to a pedagogical activity.

The musical expansion of Old Viennese classics spread throughout Europe, in particular: within the framework of the regular Concert Spirituels in 1755 - 1765, which took place during religious holidays in Tuileries Palace and included a sacred, secular instrumental, chamber and symphonic music. Nine successful concerts of G. C. Wagenzail took place. For comparison, C. W. Gluck performed there eight times, W. A. Mozart - 10, D. von Dittersdorf $(1739-1799)-6$, I. Holzbauer $(1711-1783)-3$. The symphonies, sacred and chamberinstrumental music of G. C. Wagenzail sounded (Hausswald, G. 1952, p. 48). G. C. Wagenzail used a large orchestra: "The symbiosis of Italian melody, French harmony and German form (structure) formed a high Austrian compositional style" (Scholz-Michelitsch, 1980, p. 60).

The English composer, music historian and organist Charles Burney (1726 - 1814) said the following words about the piano work of G. C. Wagenzail: "The virtuoso, who used all the possibilities of the instrument, the experience of a pedagogue, who develops the technique and musical abilities of his students" (Scholz-Michelitsch, 1980, p. 61). Owing to Charles Burney, there is a thorough description of the activity of a creative life of G. C. Wagenzail, when he created his works in 1772, when he lived in Vienna. Travelling in Europe, Ch. Berney published the books "Contemporary State of Music in France and Italy" (1771), "Contemporary State of Music in Germany, the Netherlands, and the United Kingdom" (1773), and a four-volume book "History of Music" (1776 - 1789). Despite the 
active popularization of G. K. Wagenzail by Ch. Berney, a creative fame of G. K. Wagenzail's faded as Viennese classics began to enter the music scene. Summarizing the achievements of Old Viennese classics, in 1861 the famous historian Constantin von Wurzbach-Tannenberg (1818 - 1893) enrolled opera reformer C. W. Gluck, G. K. Wagenzail to the prominent artists of Maria-Theresa era, along with the founder of Baroque architecture, Fischer von Ehrlich, whose works are: Schloß Schönbrunn Palace, Winter Palace (Winterpalais) of Prince E. Savoysky, Karlskirche in Vienna.

The Conclusions. Thus, there were significant reform changes in the cultural, sociostate and religious life of the Austrian Empire during the reign of Empress Maria-Theresa $(1740-1780)$. The musical life of Vienna was characterized by the intensity and developed forms of music and concert practice. Old Viennese musicians of Maria-Theresa era created a favourable foundation for the activities of Viennese musical classics, laying the foundations in all areas of the artistic process - composer's creative work, performing practice, pedagogue's practice, music education infrastructure and concert entertainment institutions. Among the galaxy of contemporary composers-performers stood out the figures of G. K. Wagenzail, G. Reuter, M. G. Monn, J. Starzer and J. K. Manna, who were united by a common geographical location (the city of Vienna) and the same period of time (the reign of Maria-Theresa), which coincided with the peak of their creative activity. According to E. Braudo, each of the representatives of Old Viennese school individually "strengthened the foundations of the new instrumental style, both in symphonic and instrumental music" (Braudo, 1925, p. 87).

The prospects for further research in this direction are to analyze the historical era of Maria-Theresa in the projection of the Ukrainian cultural, artistic and religious space.

Acknowledgments. We express sincere gratitude to all members of the editorial board for consultations provided during the preparation of the article for printing.

Funding. The authors received no financial support for the research, authorship, and/or publication of this article.

\section{BIBLIOGRAPHY}

Braudo, E. M. (1925). Vseobshchaya istoriya muzyki [General History of Music]. Vol. 2. Moskva, 266 p. [in Russian]

Kirillina, L. V. (1996). Klassicheskiy stil'v muzyke XVIII - nachala XIX vekov: Samosoznaniye epokhi i muzykal'naya praktika [Classical style in music of the 18th and early 19th centuries: Self-consciousness of the epoch and musical practice]. Moskva: Moskovskaya gosudarstvennaya konservatoriya,192 p. [in Russian]

Taylor, A. J. P. (2002). The Habsburg Monarchy 1809 - 1918. A History of the Austrian Empire and Austria-Hungary [The Habsburg Monarchy 1809 - 1918. A History of the Austrian Empire and Austria-Hungary]. Lviv: VNTK-Klasyka. 268 p. [in English]

Shup'yana, M. (2013). Reformuvannya suspil'noho ta derzhavnoho zhyttya v Avstriys'kiy imperiyi za chasiv pravlinnya imperatrytsi Mariyi Tereziyi (1740 - 1780 rr.) [Reforming public and public life in the Austrian Empire during the reign of Empress Maria Theresa (1780 - 1780)]. Visnyk Lvivskoho universytetu. Seriya yurydychna - Lviv University Bulletin. Series Law, 58, 126-134. [inUkrainian]

Shushkova, O. M. (2002). Ranneklassicheskaya muzyka: estetika, stilevyye osobennosti, muzykal'naya forma [Early classical music: aesthetics, style features, musical form]. Vladivostok: DVGU. 240 p. [in Russian]

Die Habsburgermonarchie. (2003). Die Habsburgermonarchie 1848 - 1918. [The Habsburg Monarchy 1848 - 1918]. Band III/1: Die Völker des Reiches. Wandruszka Adam, Urbanitsch Peter (Hrsg.). Verlag: VÖAW. [in German] 
Hausswald, G. (1952). Der Divertimento-Begriff bei Georg Chr. Wagenseil [The divertimento term in Georg Chr. Wagenseil]. Archiv für Musikwissenschaft. IX Jahrg., H. 1 (pp. 45-50). Leipzig: Trossingen. [in German]

Scholz-Michelitsch, H. (1972). Das Orchester - und Kammermusikwerk von Georg Christoph Wagenseil: thematischer Katalog [The orchestral and chamber music work of Georg Christoph Wagenseil: thematic catalog]. Wien: Böhlau, Tabulaemusicae Austriacae, 228 p. [in German]

Scholz-Michelitsch, H. (1980). Georg Christoph Wagenseil Hochkomponist und Hofklaviermeister der Kaiserin Maria-Theresia [Georg ChristophWagenseil High-composer and court piano master of the Empress Maria-Theresia]. Wien: Wilhelm Braumüller Universität; Verlagsbuchhandlung Ges. m.b. H.A, 109 p. [in German]

The article was received on October 23, 2019. Article recommended for publishing 26/08/2020. 